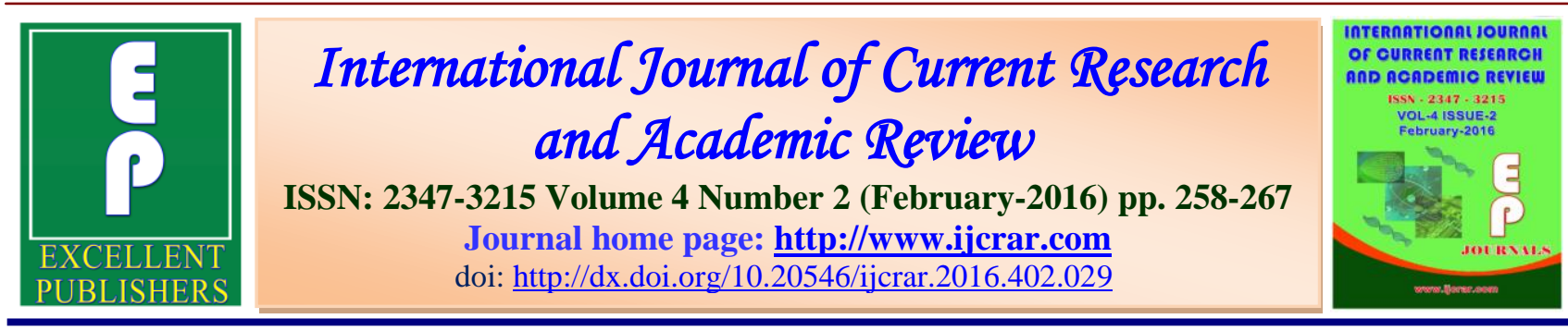

\title{
Use of social media by agricultural science students in Michael Okpara University of Agriculture, Umudike, Abia state, Nigeria
}

\author{
Ogbonna, Isaac M* and Onuoha, Juliet \\ University Library, Michael Okpara University of Agriculture, Umudike, Abia State, Nigeria \\ *Corresponding author
}

\section{KEYWORDS}

Social media, agricultural science students, Michael Okpara University of agriculture, Umudike

\section{A B S T R A C T}

This study examines the use of social media by undergraduate students in core agricultural science disciplines in Michael Okpara University of Agriculture, Umudike, Abia State, Nigeria. The study covers four colleges that represent the colleges that offer core agricultural science courses. There are eleven colleges in the university. Four objectives and four research questions were stated. The researchers adopted descriptive survey research design for the study. The area of study is the Michael Okpara University of Agriculture, Umudike, Abia State, Nigeria. Undergraduate students in their third and fourth years of study from the four core agricultural science colleges were selected and surveyed. Proportionate stratified sampling technique was used in selecting the sample while the research instrument used in data collection was questionnaire. The population of the study is made up of 1,666 third and fourth year undergraduate students of the four core agricultural science colleges. Data collected were analyzed using frequency counts, percentages and mean and presented in tables for clarity. Findings reveal that all the students are familiar with at least one of the various social media websites under study. The study also reveals that Wikipedia is more popular with the students than the other social media channels under study. The purposes of use of the social media by the students were found to include: interaction with friends; obtaining recreational information; sharing ideas, information and for up-date news; enhancing social presence; and for exposure related to education. The paper recommends, among others, that university libraries should regularly provide information on its activities and services to the students through the social media as this will draw students towards using social media more for educational purposes. 


\section{Introduction}

Information and communication technology has made it possible for library users, particularly students in higher educational institutions, to access information through a wide range of channels and sources. Social media is one of the channels. Social media are internet-based tools for sharing information and discussing issues of interest among people. Walter (2012) states that since the internet is making those tools more interactive the term social media was coined to refer to the highly interactive qualities of newer forms of electronic media which allow different ways of communicating and sharing information than $\mathrm{TV}$, radio and newspapers. From research reports, the past decade has witnessed a rapid growth in popularity and use of social media for various purposes. It has reshaped the manner in which individuals and organizations collaborate, communicate and create relationship with colleagues. Social media have continued to increase in popularity among the undergraduates and other user groups.

Although largely used for social purposes, some social media platforms such as YouTube and Wikipedia have been emerging as important sources of information (Head and Eisenberg, 2010). Unlike traditional information sources, the information available through social media is created and shared by interested users. Social media include wikis, social news, social networking such as Facebook, Myspace, Linkedln, and Social photo/ video sharing such as You Tube.

Kim et al. (2013) state that while there are different ways to categorize social media, its typology is often based on the main function and purpose of use, such as for blogging, microblogging (e.g. Twitter), social networking (e.g. facebook), collaborative knowledge production and sharing (e.g. wikipedia), multimedia sharing (e.g. You Tube) and sharing reviews and opinions (e.g. social Q \& A, user reviews). As a result of the little scrutiny social media undergoes, the quality of the information gained from social media varies widely. Despite quality concern, the use of social media is prevalent among the undergraduates.

Michael Okpara University of Agriculture, Umudike (MOUAU) is in Abia State, Nigeria. Abia State is in the Eastern part of Nigeria. The university is an institution of higher education with emphasis on the teaching and learning of agricultural science at undergraduate and postgraduate levels. Although a university of agriculture with emphasis on agricultural related disciplines, MOUAU offers courses in other nonagricultural disciplines such as Electrical Engineering, Computer Engineering, Chemistry Education, etc. as currently obtained in Universities of Agriculture in Europe and America. This study, therefore, examines whether undergraduate students in core agricultural science disciplines in the university use social media and for what purpose. Data were collected in response to research questions that include: which of the following social media categories are you familiar with? ; How long have you been using the following social media categories? To what extent do you use the following social media websites? And why do you choose to use the following social media?

Social media refers to mobile and web-based technology applications used for the generation and discussion of information in various forms such as textual, pictorial, audio or video forms (Bhatti, 2014). In its definition, Merriam-Webster (2015), states that social media are "forms of electronic communication through which users create online communities to share information, 
ideas, personal messages, and other contents such as videos.

Elonye (2013) writes that the most popular types of social media tools include social networking, social book marking, social recommendation, social content and blogging. According to Tropper (2007), $55 \%$ users of social media use social networking sites, mostly MySpace or Facebook. From their research work, Vrocharidon and Efthymiou (2012) write that students adopt instant messaging, emails and social networking sites frequently for social and educational purposes.

Ayu and Abrizah (2011) reported that most of the libraries are using social networking site like Facebook for their advertisement and marketing of their services. Nicholas, Walkinson, Rowlands and Jubb (2011) observed that facebook and Twitter is frequently used by the University students of UK.

The researchers found that many libraries are not connecting with the social media which they can use to keep in contact with the users. Raskin (2006) states that the most popular and interesting social network is the facebook. Head and Eisenberg (2011) and Kim, Yoo-Lee and Sin (2011) pointed out that some studies suggest that students may be using various social media platforms in order to satisfy their academic and everyday-life information needs.

Kaplan and Haenlein (2010) noted that the advent of social media has brought about significant impacts on daily life, not only changing the ways in which people stay connected, but also presenting considerable opportunities and challenges for librarians and educators. Brenner (2012) writes that it is already known that social networking sites (SNS) such as facebook are widely used while Zickuhr (2010) states that about $66 \%$ of online adults use SNS. Denning, Horning, Parnas and Weinstein (2005), Grimes and Boening (2001) agree that the use of social media as an information source is of concern to information literature librarians and educators, in part due to the varying quality of the information available via these media.

Partly due to the case of forwarding messages with a single click, information can be forwarded almost instantly via one's social networks. Undiscerning social media users may, therefore, unwillingly contribute to the spread of misinformation. Rumours and inaccurate information can quickly and easily be distributed to a large number of users' worldwide (Ball and Lewis, 2011). Seeing the same information on many sites, and being posted by many different individuals, unsuspecting readers may misjudge the information as being credible (Kim, Sin and Yoo-Lee, 2013).

Social media offer exciting opportunities for users. They facilitate interactive and collaborative knowledge production and sharing. Social media can also provide local and current information, and serve as outlets for viewpoints and voices that are not typically conveyed by traditional or dominant media outlets (Bertot and Grines, 2010; Srinivasan, 2006). If used properly and with care, social media can be powerful instrument of information and transformative tools.

This study will help better understanding of the use of social media by agricultural students in Michael Okpara University of Agriculture, Umudike. It will also provide suggestions to the University Library on the need for promotion of the use of social media by the library users. 
The main objectives of this study includes, to explore the familiarity of social media among agricultural science undergraduates. To know how long the students have been using the social media categories. To find out the extent of usage of the social media website. And also to find out the purposes for using each social media.

\section{Research Methodology}

The researchers used descriptive survey research design for this study. The area of study is Michael Okpara University of Agriculture, Umudike in Abia State, Nigeria. Undergraduate students in their third and fourth years of study from four core agricultural science colleges were selected and surveyed. Convenient sampling method was used and survey was conducted through questionnaire. Close ended questions were asked the respondents. Responses from 829 students were obtained.

The population of the study is made up of 1,666 third and fourth year undergraduate students of four core agricultural science colleges in the Michael Okpara University of Agriculture, Umudike. These colleges are: College of Agricultural Economics, Rural Sociology and Extension (CAERSE); College of Crop and Soil Sciences (CCSS); College of Agricultural Science and Animal Production (CASAP); and College of Natural Resources and Environmental Management (CNREM).

Proportionate stratified sampling technique was adopted in selecting the sample as shown in Table 1 below. Out of 1,666 students' population, 1,000 students constitute the sample size. This represents $60 \%$ of the population size. A total of 1,000 copies of the questionnaire were distributed but 829 copies, representing approximately $83 \%$, were returned and used for the study.
Data collected were analyzed using frequency counts, percentages, and mean and presented in tables for clarity.

\section{Results and Discussion}

Research Question 1: Which of the following social media categories are you familiar with?

Table two above shows the frequency of familiarity with social media categories by the agricultural science students. The table indicated that the largest number of students, 726 representing $88 \%$ is familiar with Wikipedia followed by social networking sites (e.g. facebook) with 635 students representing $77 \%$ that are familiar with the social media category. Linkedin ranked third in the most familiar social media category with 515 students response representing $62 \%$ attesting familiarity with it.

Research Question 2. How long have you been using the following social media categories?

Table three presents the length of time of usage of social media categories. Out of 515 students that indicated familiarity with Linkedin, only $16 \%$ (82) of the students have been using Linkedin for two years or more while for the 726 students that are familiar with Wikipedia, the largest number of students, 348 representing $48 \%$, use the social media website (Wikipedia) for two years or more. Microblogs have 315 students that are familiar with it and out of this number, 180 representing $57 \%$, use the website for less than one year.

Research Question 3. To what extent do you use the following social media websites?

Table four above shows the extent of use of social media websites by the agricultural 
Int.J.Curr.Res.Aca.Rev.2016; 4(2): 258-267

science students of Michael Okpara University of Agriculture, Umudike. Out of the 635 respondents that are familiar with the social networking sites (eg Facebook), 212 respondents representing $33.39 \%$ use the social media always while only 82 of the students representing $12.91 \%$ rarely use the social media (Facebook). Also, out of the 345 students that are familiar with the social Question and Answer sites, the highest number of students, 165 representing $47.82 \%$ rarely uses the site, while only 19 respondents representing $5.51 \%$ use the website always.

Research Question 4. Why do you choose to use the following social media?

Responses gathered from table 5 above show that the generally and most accepted reasons or purposes of using the various social media websites include for connecting/interacting with friends and to obtain recreational information. In Facebook, the most accepted purpose of use is for interaction with friends which has mean rating of 4.96 while for connecting/interacting with teachers is the most rejected purpose of use of Facebook with 2.46 mean rating. As regards Wikipedia, to get background information was the most accepted reason for the use of the Wikipedia websites with 4.94 mean rating. In YouTube, sharing ideas, information and update news is the most accepted reason for the use of the YouTube website with 4.70 mean rating while in Twitter, interacting with friends is the most accepted reason for its use with 4.58 mean rating.

Table.1 The Population and Sample Size

\begin{tabular}{|l|l|l|l|}
\hline S/N & \multicolumn{1}{|c|}{ Colleges } & Population & $\begin{array}{l}\text { Sample } \\
\text { size }\end{array}$ \\
\hline 1 & College of Agricultural Economics, Rural Sociology and Extension & 804 & 483 \\
2 & College of Crop and Soil Sciences & 320 & 192 \\
3 & College of Agricultural Science and Animal Production. & 262 & 157 \\
4 & College of Natural Resources and Environmental Management & 280 & 168 \\
\cline { 3 - 4 } & & 1,666 & 1,000 \\
\hline
\end{tabular}

Table.2 Frequency of Familiarity with Social Media Categories

\begin{tabular}{|l|l|l|l|l|l|l|l|}
\hline S/N & Social Media Categories & \multicolumn{2}{l|}{ Yes } & \multicolumn{2}{l|}{ No } & \multicolumn{2}{l|}{ Total } \\
\cline { 3 - 8 } & & Freq & $\%$ & Freq & $\%$ & Freq & $\%$ \\
\hline 1 & Wikipedia & 726 & 88 & 103 & 12 & 829 & 100 \\
2 & Social networking sites (e.g. facebook) & 635 & 77 & 194 & 23 & 829 & 100 \\
3 & Video sharing sites (e.g. You Tube) & 284 & 34 & 545 & 66 & 829 & 100 \\
4 & Social Q \& A sites (e.g. Yahoo Answers) & 345 & 42 & 484 & 58 & 829 & 100 \\
5 & Blogs & 286 & 34 & 543 & 66 & 829 & 100 \\
6 & Microblogs (e.g. Twitter) & 315 & 38 & 514 & 62 & 829 & 100 \\
7 & Google & 352 & 42 & 477 & 58 & 829 & 100 \\
8 & Linkedin & 515 & 62 & 314 & 38 & 829 & 100 \\
\hline
\end{tabular}


Int.J.Curr.Res.Aca.Rev.2016; 4(2): 258-267

Table.3 Frequency of Length of Time of Using Social Media Categories

\begin{tabular}{|c|c|c|c|c|c|c|c|c|c|c|c|}
\hline \multirow[t]{2}{*}{$\begin{array}{l}\mathbf{S} / \\
\mathbf{N}\end{array}$} & \multirow[t]{2}{*}{ Social Media Websites } & \multicolumn{2}{|c|}{$\begin{array}{l}\text { Less than } \\
1 \mathrm{yr}\end{array}$} & \multicolumn{2}{|c|}{1 year } & \multicolumn{2}{|c|}{ 1-2 years } & \multicolumn{2}{|c|}{$\begin{array}{l}2 \text { years and } \\
\text { above }\end{array}$} & \multicolumn{2}{|l|}{ Total } \\
\hline & & Freq & $\%$ & Freq & $\%$ & Freq & $\%$ & Freq & $\%$ & Freq & $\%$ \\
\hline 1 & Wikipedia & 41 & 6 & 130 & 18 & 207 & 28 & 348 & 48 & 726 & 100 \\
\hline 2 & $\begin{array}{l}\text { Social networking sites } \\
\text { (e.g. facebook) }\end{array}$ & 19 & 3 & 70 & 11 & 413 & 65 & 133 & 21 & 635 & 100 \\
\hline 3 & $\begin{array}{l}\text { Video sharing sites } \\
\text { (e.g. You Tube) }\end{array}$ & 168 & 59 & 85 & 30 & 23 & 8 & 8 & 3 & 284 & 100 \\
\hline 4 & $\begin{array}{l}\text { Social Q \& A sites } \\
\text { (e.g.Yahoo Answers) }\end{array}$ & 152 & 44 & 176 & 51 & 7 & 2 & 10 & 3 & 345 & 100 \\
\hline 5 & $\mathrm{~B} \log \mathrm{s}$ & 109 & 38 & 137 & 48 & 26 & 9 & 14 & 5 & 286 & 100 \\
\hline 6 & $\begin{array}{l}\text { Microblogs } \\
\text { (e.g. Twitter) }\end{array}$ & 180 & 57 & 79 & 25 & 31 & 10 & 25 & 8 & 315 & 100 \\
\hline 7 & Google & 144 & 41 & 67 & 19 & 113 & 32 & 28 & 8 & 352 & 100 \\
\hline 8 & Linkedin & 175 & 34 & 155 & 30 & 103 & 20 & 82 & 16 & 515 & 100 \\
\hline
\end{tabular}

Table.4 Frequency of Extent of Use of Social Media Websites

\begin{tabular}{|c|c|c|c|c|c|c|c|c|c|c|c|c|c|}
\hline \multirow[t]{2}{*}{$\mathrm{SN}$} & \multirow{2}{*}{$\begin{array}{ll}\text { Social } & \text { media } \\
\text { websites } & \end{array}$} & \multicolumn{2}{|c|}{ Always } & \multicolumn{2}{|c|}{ Frequently } & \multicolumn{2}{|c|}{ Sometimes } & \multicolumn{2}{|c|}{ Rarely } & \multicolumn{2}{|c|}{ Never } & \multicolumn{2}{|c|}{ Total } \\
\hline & & $\mathrm{F}$ & $\%$ & $\mathrm{~F}$ & $\%$ & $\mathrm{~F}$ & $\%$ & $\mathrm{~F}$ & $\%$ & $\mathrm{~F}$ & $\%$ & $\mathrm{~F}$ & $\%$ \\
\hline 1 & Wikipedia & 154 & 21.21 & 348 & 47.93 & 104 & 14.33 & 120 & 16.53 & & 0 & 726 & 100 \\
\hline 2 & $\begin{array}{l}\text { Social networking } \\
\text { sites (Facebook }\end{array}$ & 212 & & 180 & 28.35 & 161 & 25.35 & 82 & 12.91 & - & 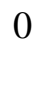 & 635 & 100 \\
\hline 3 & $\begin{array}{l}\text { Video sharing } \\
\text { sites (YouTube) }\end{array}$ & 24 & 8.45 & 50 & 17.61 & 124 & 43.66 & 86 & 30.28 & - & 0 & 284 & 100 \\
\hline 4 & $\begin{array}{l}\text { Social Q/A sites } \\
\text { (YahooAnswers) } \\
\text { Blogs }\end{array}$ & 19 & 5.51 & 29 & 8.41 & 132 & 38.26 & 165 & 47.82 & - & 0 & 345 & 100 \\
\hline 5 & blogs & 28 & 9.79 & 50 & 17.48 & 98 & 34.27 & 110 & 38.46 & - & 0 & 286 & 100 \\
\hline 6 & & 7 & 2.22 & 20 & 6.35 & 215 & 68.25 & 73 & 23.18 & - & 0 & 315 & 100 \\
\hline 7 & & 24 & 6.82 & 54 & 15.34 & 221 & 62.78 & 53 & 15.06 & - & 0 & 352 & 100 \\
\hline 8 & Linkedin & 22 & 4.27 & 213 & 41.36 & 265 & 51.46 & 15 & 2.91 & - & 0 & 515 & 100 \\
\hline
\end{tabular}


Table.5 Purpose of Use of Social Media

\begin{tabular}{|c|c|c|c|c|c|c|c|c|}
\hline & Purpose of Use & SA & A & $\mathrm{NO}$ & $\mathrm{D}$ & SD & Mean & Decision \\
\hline & Facebook & & & & & & & \\
\hline 1 & To get background information & 168 & 186 & 6 & 125 & 150 & 3.15 & Accepted \\
\hline 2 & For Interaction with friends & 612 & 23 & - & - & - & 4.96 & Accepted \\
\hline 3 & $\begin{array}{l}\text { For sharing ideas, information and for } \\
\text { up-date news }\end{array}$ & 481 & 152 & 2 & - & - & 4.75 & Accepted \\
\hline 4 & $\begin{array}{l}\text { For Connecting/interacting with } \\
\text { teachers }\end{array}$ & 39 & 106 & 20 & 418 & 52 & 2.46 & Rejected \\
\hline 5 & For enhancing social presence & 473 & 160 & 2 & - & - & 4.74 & Accepted \\
\hline 6 & For exposure related to education & 266 & 361 & 8 & - & - & 4.40 & Accepted \\
\hline 7 & To obtain recreational information & 538 & 92 & 5 & - & - & 4.83 & Accepted \\
\hline & Wikipedia & & & & & & & \\
\hline 1 & To get background information & 684 & 42 & - & - & - & 4.94 & Accepted \\
\hline 2 & For Interaction with friends & 255 & 391 & 15 & 60 & 5 & 4.14 & Accepted \\
\hline 3 & $\begin{array}{l}\text { For sharing ideas, information and for } \\
\text { up-date news }\end{array}$ & 451 & 252 & - & 23 & - & 4.55 & Accepted \\
\hline 4 & $\begin{array}{l}\text { For Connecting/interacting with } \\
\text { teachers }\end{array}$ & 76 & 88 & - & 309 & 253 & 2.20 & Rejected \\
\hline 5 & For enhancing social presence & 281 & 396 & 9 & 30 & 10 & 4.25 & Accepted \\
\hline 6 & For exposure related to education & 310 & 412 & - & 4 & - & 4.41 & Accepted \\
\hline 7 & To obtain recreational information & 204 & 221 & 51 & 215 & 35 & 4.41 & Accepted \\
\hline & YouTube & & & & & & & \\
\hline 1 & To get background information & 90 & 194 & - & - & - & 4.31 & Accepted \\
\hline 2 & For Interaction with friends & 70 & 120 & 25 & 48 & 21 & 3.59 & Accepted \\
\hline 3 & $\begin{array}{l}\text { For sharing ideas, information and for } \\
\text { up-date news }\end{array}$ & 214 & 60 & 5 & 5 & - & 4.70 & Accepted \\
\hline 4 & $\begin{array}{l}\text { For Connecting/interacting with } \\
\text { teachers }\end{array}$ & 10 & 42 & 20 & 200 & 12 & 2.42 & Rejected \\
\hline 5 & For enhancing social presence & 141 & 128 & - & 15 & - & 4.39 & Accepted \\
\hline 6 & For exposure related to education & 196 & 70 & 8 & 10 & - & 4.59 & Accepted \\
\hline 7 & To obtain recreational information & 50 & 61 & 5 & 160 & $\mathbf{8}$ & 2.94 & Rejec ted \\
\hline & Yahoo Answers & & & & & & & \\
\hline 1 & To get background information & 80 & 69 & 50 & 120 & 26 & 3.16 & Accepted \\
\hline 2 & For Interaction with friends & 85 & 79 & 61 & 94 & 26 & 3.29 & Accepted \\
\hline 3 & $\begin{array}{l}\text { For sharing ideas, information and for } \\
\text { up-date news }\end{array}$ & 78 & 70 & 58 & 107 & 32 & 3.15 & Accepted \\
\hline 4 & $\begin{array}{l}\text { For Connecting/interacting with } \\
\text { teachers }\end{array}$ & 5 & 16 & 89 & 216 & 19 & 2.33 & Rejected \\
\hline 5 & For enhancing social presence & 91 & 69 & 35 & 129 & 21 & 3.23 & Accepted \\
\hline 6 & For exposure related to education & 101 & 75 & 23 & 132 & 14 & 3.33 & Accepted \\
\hline 7 & To obtain recreational information & 28 & 51 & 12 & 206 & 48 & 2.43 & Rejected \\
\hline & Twitter & & & & & & & \\
\hline 1 & To get background information & 40 & 81 & 32 & 136 & 26 & 2.91 & Rejected \\
\hline 2 & For Interaction with friends & 215 & 85 & - & 15 & - & 4.58 & Accepted \\
\hline 3 & $\begin{array}{l}\text { For sharing ideas, information and for } \\
\text { up-date news }\end{array}$ & 218 & 38 & 5 & 50 & 4 & 4.32 & Accepted \\
\hline 4 & $\begin{array}{l}\text { For Connecting/interacting with } \\
\text { teachers }\end{array}$ & 35 & 71 & 15 & 125 & 69 & 2.61 & Rejected \\
\hline 5 & For enhancing social presence & 121 & 171 & 4 & 19 & - & 4.25 & Accepted \\
\hline
\end{tabular}


Int.J.Curr.Res.Aca.Rev.2016; 4(2): 258-267

\begin{tabular}{|c|c|c|c|c|c|c|c|c|}
\hline 6 & For exposure related to education & 115 & 167 & - & 30 & 3 & 4.14 & Accepted \\
\hline 7 & To obtain recreational information & 127 & 115 & - & 58 & 15 & 3.93 & Accepted \\
\hline 1 & $\begin{array}{l}\text { Linkedin } \\
\text { To get backoround information }\end{array}$ & 98 & 107 & 7 & 229 & 74 & 285 & Reiected \\
\hline 2 & For Interaction with friends & 215 & 182 & 21 & 91 & 6 & 3.98 & Accepted \\
\hline 3 & $\begin{array}{l}\text { For sharing ideas, information and for } \\
\text { up-date news }\end{array}$ & 227 & 171 & 28 & 79 & 10 & 4.02 & Accepted \\
\hline 4 & $\begin{array}{l}\text { For Connecting/interacting with } \\
\text { teachers }\end{array}$ & 68 & 25 & 22 & 315 & 85 & 2.37 & Rejected \\
\hline 5 & For enhancing social presence & 155 & 178 & 18 & 122 & 42 & 3.54 & Accepted \\
\hline 6 & For exposure related to education & 311 & 197 & - & 7 & - & 4.56 & Accepted \\
\hline 7 & To obtain recreational information & 52 & 87 & 27 & 271 & 78 & 2.54 & Rejected \\
\hline & Blogs & & & & & & & \\
\hline 1 & To get background information & 38 & 34 & 38 & 156 & 20 & 2.69 & Rejected \\
\hline 2 & For Interaction with friends & 169 & 105 & - & 6 & 6 & 4.48 & Accepted \\
\hline 3 & $\begin{array}{l}\text { For sharing ideas, information and for } \\
\text { up-date news }\end{array}$ & 151 & 101 & 5 & 21 & 8 & 4.27 & Accepted \\
\hline 4 & $\begin{array}{l}\text { For Connecting/interacting with } \\
\text { teachers }\end{array}$ & 21 & 28 & 13 & 214 & 10 & 2.42 & Rejected \\
\hline 5 & For enhancing social presence & 98 & 107 & 7 & 70 & 4 & 3.70 & Accepted \\
\hline 6 & For exposure related to education & 112 & 119 & 13 & 42 & - & 4.05 & Accepted \\
\hline 7 & To obtain recreational information & 42 & 61 & 38 & 134 & 11 & 2.29 & Rejected \\
\hline
\end{tabular}

\section{Discussion and Findings}

From the study, all the students are familiar with at least one of the various social media websites under study. This is not surprising considering the growing popularity of social media. It also attests that social media is popular among the agricultural students of Michael Okpara University of Agriculture, Umudike. The study also reveals that most of the students are familiar with Wikipedia more than with other social media. This is quite understandable as students usually visit the Wikipedia website while writing their take-home assignments and research works. This is because, according to the findings, Wikipedia is mostly used by the students to obtain background information on their research topics.

The finding also shows that greater number of the students have been using Wikipedia for two years or more. Using the Wikipedia website to carry out assignments in addition to the library resources is beneficial to the academic progress of the students. The finding that none of the social media websites is not used by the students further emphasizes the importance of social media to the students.

The research revelation of the major purposes of using the social media by the students include: interaction with friends; obtaining recreational information; sharing ideas, information and for up-date news; enhancing social presence; and for exposure related to education. These findings are indicative that libraries can use the social media to promote their services to the students. It also implies that libraries can use social media in informing library users about new resources and also enhance library instruction. The results as obtained from this study revealed that most of the students are familiar with the social media that are relevant in their educational pursuit. It also revealed that most of the students are using 
the social media that are helpful to their educational pursuit more frequently and for longer period. The implication of this is that lecturers can explore the social media platform to interact with students on academic matters.

\section{Conclusion}

The social media presence of Agricultural Science students of Michael Okpara University of Agriculture, Umudike offers opportunity and new platform for the university authority, the university library and the lecturers to reach out to the students with information, directives and instructions related to their educational pursuit in the university. The result of this study has led to the conclusion that though agricultural science students of Michael Okpara University of Agriculture, Umudike use the social media, their main purpose of using the social media vary from one social media platform to the other. Their use of most of the platforms is not, however, directly related to their academic pursuit or interaction with their teachers on academic issues.

The faculty members should explore the social media in interacting with the students on academic matters. This will increase the students' use of the social media for research and academic purposes.The university library should regularly provide information on its activities and services to the students through the social media. This will also draw the students towards the use of social media more for academic purposes. The university authority should ensure that the library provides free internet access and facilities to the students. This will break the barrier for using the social media by the students because of lack of fund or air time.

\section{References}

Ayu, R., \& Abrizah, A. (2011). Do you facebook? usage and applications of facebook pages among academic Libraries in Malaysia. The International Information and Library Review., 43, pp. 239-249.

Ball, J., \& Lewis, P. (2011, Dec 7). Twitter and the Roots: How the News spread. Retrieved from http:// www.guardian. co.uk/2011/dec/07/twitter-riots-hownews-spread.

Bertot, J. C., \& Grines, J. M. (2010). Using ICTs to create a culture of Transparency; E- Government and Social media as openness and Anticorruption Tools for societies. Government Information Quarterly, 27 (3), pp. 264-271.

Bhatti, R. (2014). Social media's magnetism towards Researchers: Implications for Libraries. Retrieved 2014, from Library Philosopy and Practice: http://digital commons.url.edu/Libphiprac/1181

Brenner, J. (2012). Pew Internet: Social Networking. Retrieved from http://pewinternet.org/complemtary/2 012/March/Pew-Internet-social-

Networking-full-detail.aspx.

Denning, P., Horning, J., Parnas, D., \& weinstein, L. (2005). Wikipedia Risks. Communication of the ACM, 48 (12), pp. 152-162.

Elonye,G.U.(2013).Using Social Media for Innovative Library and Information Services .in A.O.Issa,K,N.Igwe and C.P.Uzuegbu.Provision of Library and Information Services to Users in the Era of Globalization.Lago:Watodanny Visual Concept.

Grimes, D. J., \& Boening, C. H. (2001). Worries withthe web: A Look at student use of web resources. College 
and Research Libraries, 62 (1), pp. 11-22.

Head, A. J. \& Eisenberg, (2011). How College Students use the Web. proceedings of the ASIST Annual Meeting 48. Retrieved from http://onlinelibrary.Willey.com/doi/10 /002/meet.2011.14504801283/fall

Head, A. J. (2010). How Today's CollegeStudents the Wikipedia for course -related reseach. First Monday. Retrieved from http://www. firstmonday .org/htbin/cgiwrap/bin/ojs/index.php/f m/view Article/2830/2476

Kaplan, A. M., \& Haenlein, M. (2010). Users of the world, unite! the challenges and opportunities of social media. Business Horizons, 53 (1), pp. 59-68.

Kim, K.S., Sin, S.C.J. \& Yoo-Lee, E. Y. (2013). Undergraduates use of social Media as Information Sources College and Research Libraries. Retrieved from http://crL.crL.org/content/early/2013/ 02/06/crL 13-455

Kim, K.-S., Yoo-Lee, E. Y., \& Sin, S.-C. J. (2011). Social Media as Information source: Undergraduates use of Evaluation Behaviour. Retrieved from Proceedings of the ASIST Annual Meeting 48: http://OnlineLibrary. wiley.com/doi/10.1002/meet.2011. 1450801283/fall
Merriam-Webster. (2012). Social Media. Retrieved from http://www.merriamwebster.com/dictionary/social $\% 20$ media

Nicholas, D. W; Rowlands, A.and Jubb, M. (2011). Social Media,Academic Research and the Role of University Libraries. Journal of Academic Librarianship, 37(5), 373-375.

Raskin, R. (2006). Facebook faces its future. Young consumers, 1, pp. 56-58.

Srinivasan, R. (2006). Indigenous Ethic and Cultural Articulations of New Media. International Journal of Cultural Studies, 9(4), 497-518.

Tropper, E. F. (2007). Social Networking in Libraries. New world Library 108 (7/8) 378-380. Retrieved from http://emeraldinsight.com/10.1108/03 074800710763662

Vrocharidon, A., \& Efthymiou, I. (2012). Computer Mediated communication for socikal and Academic purposes: Profile of use and Unversity students gratifications. Computer and Education, 58, 609-616.

Walter, L. (2012). Social Media Definition. Retrieved from http:// Personal webabout.com/od/socialmedia 101/9/social media

Zinckuhr, K. (2010). Generation 2010. Retrieved from http://Pewinternet.org/ Report/2010/Generations-2010.aspx

\section{How to cite this article:}

Ogbonna, Isaac M and Onuoha, Juliet. 2016. Use of social media by agricultural science students in Michael Okpara University of Agriculture, Umudike, Abia state, Nigeria. Int.J.Curr.Res.Aca.Rev. 4(2): 258-267. doi: http://dx.doi.org/10.20546/ijcrar.2016.402.029 